\title{
Correction to: MDLSD: study protocol for a randomised, double-masked, placebo- controlled trial of repeated microdoses of LSD in healthy volunteers
}

Robin J. Murphy ${ }^{1 *}$, Rachael L. Sumner ${ }^{1}$, William Evans ${ }^{2}$, David Menkes ${ }^{3}$, Ingo Lambrecht ${ }^{4}$, Rhys Ponton ${ }^{1}$, Frederick Sundram ${ }^{5}$, Nicholas Hoeh ${ }^{6}$, Sanya Ram ${ }^{1}$, Lisa Reynolds ${ }^{6}$ and Suresh Muthukumaraswamy ${ }^{1}$

Correction to: Trials 22, 302 (2021)

https://doi.org/10.1186/s13063-021-05243-3

Following the publication of the original article [1], we were notified that the title of Table 2 should be 'Table 2 Full exclusion criteria'.

The original article has been corrected.

\begin{abstract}
Author details
'School of Pharmacy, Faculty of Medical and Health Sciences, University of Auckland, 85 Park Road, Grafton, Auckland 1023, New Zealand. ${ }^{2}$ Mana Health, 7 Ruskin St, Parnell, Auckland 1052, New Zealand. ${ }^{3}$ Department of Psychological Medicine, Faculty of Medical and Health Sciences, Waikato Clinical Campus, Peter Rothwell Academic Centre, University of Auckland, Pembroke Street, Hamilton 3240, New Zealand. ${ }^{4}$ Regional Cancer \& Blood Service, Auckland District Health Board, 2 Park Road, Grafton, Auckland 1023, New Zealand. ${ }^{5}$ Department of Psychological Medicine, Faculty of Medical and Health Sciences, University of Auckland, 2 Park Road, Grafton, Auckland 1023, New Zealand. ${ }^{6}$ Department of Psychological Medicine, Faculty of Medical and Health Sciences, University of Auckland, 22-30 Park Avenue, Grafton, Auckland 1023, New Zealand.
\end{abstract}

Published online: 10 May 2021

\section{Reference}

1. Murphy, et al. MDLSD: study protocol for a randomised, double-masked,

placebo-controlled trial of repeated microdoses of LSD in healthy

volunteers. Trials. 2021;22:302. https://doi.org/10.1186/s13063-021-05243-3.

The original article can be found online at https://doi.org/10.1186/s13063021-05243-3.

* Correspondence: robin.murphy@auckland.ac.nz

${ }^{1}$ School of Pharmacy, Faculty of Medical and Health Sciences, University of Auckland, 85 Park Road, Grafton, Auckland 1023, New Zealand

Full list of author information is available at the end of the article

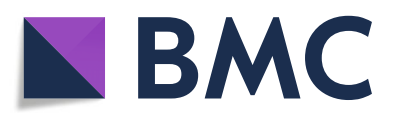

(c) The Author(s). 2021 Open Access This article is licensed under a Creative Commons Attribution 4.0 International License, which permits use, sharing, adaptation, distribution and reproduction in any medium or format, as long as you give appropriate credit to the original author(s) and the source, provide a link to the Creative Commons licence, and indicate if changes were made. The images or other third party material in this article are included in the article's Creative Commons licence, unless indicated otherwise in a credit line to the material. If material is not included in the article's Creative Commons licence and your intended use is not permitted by statutory regulation or exceeds the permitted use, you will need to obtain permission directly from the copyright holder. To view a copy of this licence, visit http://creativecommons.org/licenses/by/4.0/. The Creative Commons Public Domain Dedication waiver (http://creativecommons.org/publicdomain/zero/1.0/) applies to the data made available in this article, unless otherwise stated in a credit line to the data. 